\title{
The Role of Tuan Guru Hasanain Juaini: A Study on the Role of Tuan Guru Hasanaian Juaini in Nurul Haramain Islamic Boarding School (Pesantren), West Lombok Regency
}

\author{
Jalalussayuthy $^{1} \quad$ Bonaventura Ngarawula $^{2} \quad$ Wahyu Wiyani $^{2}$ \\ 1. Doctoral Candidate of Social Science Department, University of Merdeka Malang \\ 2. Lecture of Social Science Department, University of Merdeka Malang
}

\begin{abstract}
Tuan Guru on the island of Lombok since ancient times played multiple roles in the community, especially on the island of Lombok. In the years 1800-1899, based on history, the role Tuan Guru was more focused on efforts to unite people in their respective areas. Lastly, many Tuan Guru do not only do things in the religious field, but also in the education, social and also pay attention to the environment, as was done by Tuan Guru Hasanain Juaini. This research article raises the figure of Tuan Guru Hasanain Juaini who has phenomenal and unique abilities using descriptive qualitative role studies. This theme is interesting to research to determine the role of Tuan Guru Hasanaian Juaini as a leader in the fields of religion, social, economy and the environment. As well as what factors encourage and hinder the success of Tuan Guru Hasanain in carrying out his role.
\end{abstract}

Keywords: Tuan Guru, Pesantren, Role Study

DOI: $10.7176 / \mathrm{JESD} / 11-20-11$

Publication date:October $31^{\text {st }} 2020$

\section{Introduction}

Hasanain Juaini was born in Narmada, West Lombok Regency, West Nusa Tenggara Province on August 17, 1964. He is a prominent Tuan Guru, Head of the Pondok Pesantren (Islamic School) Nurul Haramain NW Narmada, received the Ramon Magsaysay Award in 2011 for his outstanding work in the field of caring Islamic boarding schools environment, women's empowerment and tolerance among religious communities.

When he first led the Nurul Haramain, Narmada, West Lombok, West Nusa Tenggara, the pesantren had little land and had a debt of 15 million. Hasanain Juaini immediately looked for strategies to advance the pesantren by expanding connections and creating networks with non-governmental organizations (NGOs) abroad.

In the pesantren, he teaches Islam with local wisdom and human values. In 2005, Hasanain's interest shifted to environmental preservation. An issue that has not become a crucial issue for the board of pesantren. It was at the pesantren where he nurtured around 2000 students that Hasanain's motivation and great energy emerged to make his pesantren a driving actor in the reforestation of Lombok Island. As a result, the development of reforestation is so fast and massive that many people are curious, because this big job does not only require a lot of money, but also a strong environmental commitment. Its success is not without challenges, how difficult it is to convince local people about the economic value if they want to do reforestation. Understanding of religion, as well as the culture of the Sasak Tribe, is not enough to make residents around the pesantren follow his advice. Trees must bring direct economic benefits to the surrounding community. Making people aware of the importance of trees will not be accepted by society if it is not accompanied by the "lure" of economic benefits. And the challenges are not only there. For residents, the idea was considered absurd because the land they were working on was generally sandy, without nutrients, and water sources were also scarce.

His hard work to convince the public finally paid off. The community began to be moved to help him plant hundreds of thousands of trees with seeds provided by the Islamic boarding school which was raised by Hasanain and made Lombok now much greener. Apart from being successful in persuading the community to actively plant trees, hundreds of Islamic boarding schools in NTB have replicated their pattern of success. Now around 500 Pondok Pesantren in Lombok and Sumbawa have been directly involved in the nursery and planting movement, and dozens of nursery centers have also been scattered across NTB.

In this article, the researcher raised the figure of Tuan Guru H. Hasanain Juaini, who according to the researcher has phenomenal and unique abilities. This theme is interesting to research to determine the role of Tuan Guru Hasanaian Juaini as a leader in the fields of religion, social, economy and the environment. As well as what factors encourage and hinder the success of Tuan Guru Hasanain in carrying out his role.

\section{Literature Review}

Role theory is the main theory used in this study. Soekanto (2007) states that role is a dynamic aspect of position (status), if a person exercises his rights and obligations according to his position, then he plays a role. Meanwhile, according to Biddle and Thomas in Sarwono (2013), it is stated that role is a series of formulas that limit the expected behaviors of certain position holders. This is in line with Suhardono (1994), defining that role is a set of 
benchmarks, which limits what behavior a person should do, who occupies a position. Social behavior is behavior that is specifically directed at other people (Albarracín, Dolores, Johnson, \& Zanna, 2005).

Pesantren is a traditional education in which students live together and study under the guidance of a teacher who is better known as a kiai and has a dormitory for the students to stay. The santri are located in a complex that also provides a mosque for a place of worship, a space for studying, and other religious activities with the applicable regulations in it (Dhofier, 1983). Pondok Pesantren can also be understood as educational and religious teaching institutions, generally in a non-classical way, where a kiai teaches Islamic religious knowledge to students based on books written in Arabic by medieval scholars and the students usually live in a boarding house (dormitory). In the pesantren (Prasojo, 1982), Tuan Guru is a figure who has religious knowledge in the spread of Islam on the island of Lombok. Tuan means hajj and guru means figures where they gain knowledge or figures who preach Islam. A figure like this on the island of Java is called Kyai (Noor, 2004).

The research conducted by Gunawan (2014) on Educating the Multi Role of Teachers has similarities with this research, but the difference in this study is that the discussion is more broad and specific about the multi-role of Tuan Guru Hasanaian as the leader of the Pondok Pesantren Nurul Haramain in NW Narmada, West Lombok.

The second research by Fitriani (2016), Tuan Guru's Transformative Charismatic Leadership in the Social Change of the Sasak-Lombok Community through Education which examines the social change of the Lombok community under Tuan Guru's leadership at least inspires this research because in general that is the role of Tuan Guru in Lombok Island. attached to society. Likewise with the third research by Nuh (2018), Tuan Guru Reteh Syekh 'Abdurrahman Ya'qub: Gait, Role and Thought in the Field of Islamic Education which has also played an important, major and dual role in remote areas of Indragiri Hilir, Riau. The fourth research by Khaidir (2012), The Role of Tuan Guru Kyai Haji Muhammad Zainuddin Abdul Madjid in the Development of Islamic Education at Nahdlatul Wathan also inspired a lot of this research.

\section{Method}

This research approach used a qualitative descriptive method with a study of the role of Tuan Guru Hasanain, the caretaker of the Pondok Pesantren Nurul Haramain, NW Narmada, West Lombok. Because the researcher wants to describe or describe facts or circumstances in the role of Tuan Guru Hasanaian Juaini at the Pondok Pesantren Nurul Haramain NW Narmada as the leader and also its environment. The research location was concentrated on the character of Tuan Guru Hasanain Juaini at the Pondok Pesantren Nurul Haramain, which is located in Lembuak Village, Narmada District, West Lombok Regency, West Nusa Tenggara Province.

The object of research is Tuan Guru Hasanain Juaini, who has succeeded in becoming a multi-role master teacher, not only for the cottage he leads but also for his environment. Sources of data used in this study consisted of: (1) Primary data; data sourced from the results of research in the field, through direct observation and interviews with respondents and informants at the research location, and (2) Secondary Data; sourced from official documents, books, research results, studies in the form of reports and others.

In research using qualitative methods, when the problem is not clear and certain, the researcher himself has an important role as the main instrument. Therefore, the research instrument in this study is the researcher himself using logics to carry out verification and analysis or formulate a conclusion to a phenomenon under study. Activities in the analysis include data reduction, data display, and conclusion drawing / verification.

\section{Findings}

\subsection{The Role of Tuan Guru Hasanain in the Religious Affairs}

1. Finding 1: Apart from being the leader of the Pondok Pesantren Nurul Haramain, Tuan Guru Hasanain is an active preacher in the community.

2. Finding 2: Role models for teachers and students by providing direct examples of what is seen with behavior in preserving nature and keeping the environment clean.

3. Finding 3: Tuan Guru who actively campaign about the environment and initiators who socialize a lot about environmental fiqh.

4. Finding 4: Hasanain is also often asked to be a mediator to solve problems between religions.

5. Finding 5: Forming a community for women to train and provide space for da'wah and leadership for women and a discussion forum with West Nusa Tenggara leaders who have now become meeting schools.

Minor Proposition: Hasanain grew up in the world of Pondok Pesantren and from a religious family. Both parents are preachers so that the da'i blood flows in him. His choice to become an educator in pesantren and da'i institutions for the community was inseparable from his belief that education was a strategic way to advance the nation and religion to become a spirit that moved him to continue to act for the benefit of many people.

\subsection{The Role of Tuan Guru Hasanain in the Social Sector}

1. Finding 6: Tuan Guru Hasanain often takes part in direct cleaning with teachers, students and the community 
in public places.

2. Finding 7: Care for people affected by disaster and very fond of sharing to help people who are in need.

3. Finding 8: Helping Islamic boarding schools morally and materially as well as the community. For example, sharing information through seminars, giving free tree seedlings to help improve the economy of lodges, institutions and communities.

4. Finding 9: Initiating a social donation organization "Haramain Peduli" to help people affected by natural disasters and natural disasters, as well as to stimulate the community to care about donating.

5. Finding 10: They are used to always think socially for the benefit of the general public and often make sacrifices for society without expecting anything in return.

6. Finding 11: Always take the time to attend community invitations where Hasanain is often asked to fill in / provide advice at the event.

Minor Proposition: Hasanain has only wanted to work to help the community. Because he saw so many social problems that had to be overcome and it never occurred to him to work to get an award for his work. He considered that wisdom regarding the social environment had been regulated in the Al-Qur'an so that it was from this encouragement that he was moved to convey it to the students and local residents. To change people's attitudes, Hasanain met with residents and invited them to dialogue and open their thinking horizons, even facilitating it with funds.

\subsection{The role of Tuan Guru Hasanain in Economics}

1. Finding 12: Tuan Guru Hasanain promotes greening of dry land and opens business units to finance the development and economy of the cottage and community.

2. Finding 13: Projecting Haramain mart for self-reliance and donations for consumers who shop and be the first step towards "Mall Amal".

3. Finding 14: Distributing tree seedlings for free and inviting people to plant trees to help with the living and education costs of their children and to help other Pondok Pesantren.

4. Finding 15: Forming the Bina Keluarga Sejahtera (BKS) cooperative to raise the economy of the teachers at the Pondok Pesantren Nurul Haramain, NW Narmada.

5. Finding 16: Procurement of motorbikes for ustadz / teachers to make it easier for ustadz / teachers to teach. Minor Proposition: Trees must bring direct economic benefits to the surrounding community. Making people aware of the importance of trees will not be accepted by society if it is not accompanied by the "lure" of economic benefits. Mahogany, teak, white teak, sengon, ketapang, walnuts, and various woody plants now also grow a lot on people's lands which were previously empty and arid. Dozens of water sources that were once extinct are now also popping up again, and some of the springs have an enlarged discharge. The intercropping system that was developed later also allowed the community to get products from plants and even raise livestock.

\subsection{The Role of Tuan Guru Hasanain in his Environment}

1. Finding 17: Tuan Guru Hasanain is an activator of environmental cleaning and often takes part in maintaining the cleanliness of the environment through social service activities for cleaning public places.

2. Finding 18: Doing waste processing by making a waste burning stove to help the government and the community as well as making the OSAMTU program (waste processing to completion).

3. Finding 19: Providing free tree nurseries and greening dry land / deforested forests, and motivating students and the community to plant trees.

Minor Proposition: Starting from distributing tree seeds for free to anyone who wants to plant them. Every year a million productive tree seedlings that can harvest quickly are prepared. The existence of community involvement through a continuous cycle at least has been able to change these nature conservation activities into daily culture. Likewise with independent waste management. He made the waste management program an educational material at his boarding school to train students to solve problems that they created themselves with very simple management principles. The rubbish cannot be left alone for one night. He applied this principle to the students with the doctrine that everyone must be able to overcome the problems he caused himself.

\subsection{Driving Factors that Support Tuan Guru Hasanain Juaini In Carrying Out His Role.}

1. Finding 20: Among the factors that drive the success of Tuan Guru Hasanain in carrying out his role is because he has a strong determination, independence as a person who was raised in the world of Pondok Pesantren and education that he gets from his parents who are also preachers.

2. Finding 21: Inviting by role model by going directly to the field in carrying out the program.

3. Finding 22: Are sociable and have lots of friends and companions.

4. Finding 23: Want to make Nurul Haramain an independent Pondok Pesantren and see the surrounding 
environment to be green and clean.

Minor Proposition: His great energy was also born from religion in addition to Hasanain's strong philosophy to care for the environment. That planting trees and maintaining a clean environment is one of the obligations and responsibilities of humans. Moreover, environmental wisdom has been regulated in the Quran. Another driving factor is the approach, where people should not be prohibited from cutting down trees, because humans basically need trees. But people can cut trees as long as they want to plant more than the amount they cut. For those who want to plant, it is also easier for residents to take their own seeds to nursery centers.

\subsection{Inhibiting Factors Tuan Guru Hasanain Juaini In Carrying Out His Role.}

1. Finding 24: Hasanain's persistence in his work has not been able to be followed by the community. What has been started to stimulate community awareness has not been continued by the surrounding community. As; cleaning of beaches, environment, markets and others.

2. Finding 25: It was not easy to understand the community at the start of starting a movement to care for the environment because they were not aware of the meaning of caring for the environment and maintaining cleanliness.

3. Finding 26: It is difficult to change the mindset of people who still enjoy destroying the forest and the culture of people who still litter.

4. Finding 27: The culture or the initial habits of students and students who are brought from home still need to be nurtured because they are the pioneers of community movement.

5. Finding 28: Starting without sufficient financial support and supporting skills from around.

Minor Proposition: Hasanain's difficult condition when he first led the Pondok Pesantren Nurul Haramain, NW Narmada, was the first obstacle he faced. Furthermore, convincing the residents around the pesantren of the importance of planting trees was not sufficient by understanding religion and culture but also the economic value of greening. He also had to give a direct example so that people could follow his steps by getting down and working.

\section{Conclusion}

Since ancient times, Tuan Guru on the island of Lombok played multiple roles in the community, especially on the island of Lombok in 1800-1899. Based on history, the role of the Tuan Guru has focused more on efforts to unite the people in their respective regions. People on the island of Lombok really appreciate the character of the Tuan Guru. Tuan Guru are religious and community leaders who act for society with full sincerity. In fact, many Tuan Guru who are not only co-opted do only in their fields, namely religion, but they also work in education, social affairs and also pay attention to the environment, as was done by Tuan Guru Hasanain Juaini.

What Hasanain did could serve as an example for the general public. Because it is not only limited to being Tuan Guru with the obligation to teach and educate his students, but he also plays multiple roles which rarely other Tuan Guru take on that dual role. Apart from teaching, Hasanain is also an environmental activist. He also has a strong character to think about how to help others. In addition to establishing business units to support the economy of his cottage, Hasanain also conducts nurseries which are distributed to anyone who wants to plant to protect and care for the environment and can improve the economy of the community and the pesantren who participate in planting for a later date.

The driving factors that support the success of Tuan Guru Hasanain in carrying out his role include; There is the Nurul Haramain NW Narmda Islamic boarding school, so of course it gets support from students and teachers in the boarding school, support from family, friends both at home and abroad, as well as the recitation congregation managed by Hasanain who often helps during activities what the lodge does both during cleaning, nursery and tree planting.

The inhibiting factors include; Doing without capital is certainly not easy, the results of hard work are also not visible to the family because sincerity in doing / fighting is solely for religion, society, region, nation and state. Also in the beginning it was not easy to change the mindset of the people who still like to destroy forests and litter. The initial culture of students who have just come from home as a motor of change in the midst of society also still needs to be fostered to not immediately understand the meaning of a sincere struggle.

\section{Theoretical Implications}

Tuan Guru by the Sasak people is considered a person who masters various Islamic sciences, although this assumption is sometimes exaggerated and not necessarily true. However, because of his charisma, or the outstanding charisma of his parents, they were crowned master teachers. However, Tuan Guru in the Sasak community have succeeded in culturing Islamic values into the Sasak culture which can be seen in various rituals that are still preserved and considered an integral part of the history of the existence of the Sasak people.

The name Tuan Guru by the community is not proclaimed by the person who has it, but because of the community's agreement. In the past, in Sasak society, the teacher was synonymous with the world of pesantren or 
the leadership of the pesantren. As experts in religion, they always try to tell what is right is right, and what is wrong is wrong. That is why then the Tuan Guru is considered a role model for society.

In the current context, the title Tuan Guru has begun to experience a shift in meaning. Many societies today are educated people with almost equal and uniform religious knowledge. However, the legitimacy process of their appointment as Tuan Guru (master teacher) did not happen. For this reason, at this time there has actually been a change in the value and meaning of the Tuan Guru to become a scholar.

In simple terms, the Sasak people understand the meaning of the teacher as a person who has performed the pilgrimage. People who have had the pilgrimage have the ability and expertise in the field of religion according to the level of public recognition, and have morals that are considered noble by religion and society, so that when guiding and nurturing the community, they are called the Tuan Guru Haji (hajj teacher =TGH).

The existence of Tuan Guru in the Sasak community, especially in the pesantren community, is also very central, as a driving force in running the pesantren wheels. It is in the hands of a Tuan Guru that the pesantren is located. Therefore, Tuan Guru and pesantren (Islamic boarding schools) are like two sides of a coin that go together. In fact, the teacher is not only the head of the Islamic boarding school (pesantren), but also the owner.

The Tuan Guru phenomenon has also colored politics in West Nusa Tenggara in the last decade, resulting in many typologies of Tuan Guru. There is a politician teacher who has a tendency to the world and political issues and chooses the world of politics as the field of struggle. There are also business teachers who are engaged in business and business, in addition to caring for Islamic boarding schools (pesantren).

The results of this study indicate that social behavior is a function of the person and the situation, as stated by Atiknson \& Hilgard (1983), that every human being will act differently in the same situation. Meanwhile, the multi-role Tuan Guru found in this study is in line with Krech et.al (1962) that a person's behavior reflects a collection of unique traits that he carries in a certain atmosphere.

\section{References}

(en) Albarracín, Dolores, Blair T. Johnson, \& Mark P. Zanna, (2005), "The Handbook of Attitude”. Routledge. Amanchukwu, Rose Ngozi, Stanley, Gloria Jones, Ololube, Nwachukwu Prince, 2015, "A Review of Leadership Theories, Principles and Styles and Their Relevance to Educational Management".

Berger P.L dan Luckmann T, (1990), “Tafsir Sosial Atas Kenyataan. Risalah tentang Sosiologi Pengetahuan. Penerjemah, Hasan Basari”, LP3ES. Jakarta.

Creswell, John W., (2013), “Oualitative Inquiry \& Research Design”, California: Sage Publications.

Darmawan, Indri dan Ramzi, Muhajirin, (2013). "Risalah Perjuangan Guru Wen”, Cetakan I, Jogyakarta; Ar-Ruzz Media.

Haedari, H. Amin, (2007), "Transformasi Pesantren", Jakarta: Media Nusantara.

Hindin, Micelle J., (2007), "Role Theory in George Ritzer (ed.)”. The Blackwell Encyclopedia of Sociology, Blackwell Publishing.

Juaini, Hasanain., (2015), "Lorong Kerikil Tuan Guru”, Cetakan I. Lembaga Pengkajian-Publikasi Islam dan Masyarakat (LEPPIM) IAIN Mataram.

Juaini, Hasanain. , (2016), “Dari Kitab Kuning Menuju Gerakan Kitab Hijau”, Cetakan I. Ponpes Nurul Haramain NW Narmada : Kurnia Kalam Semesta.

Kevin J. Christiano, et al., 2nd ed., (2008), "Sociology of Religion: Contemporary Developments”, Lanham, MD: Rowman \& Littlefield Publishers.

Krech et.al. (1962), "Individual in Society”, Bandun Tokyo: McGraw-Hill Kogakasha.

Madjid, Nurcholis. (1997), "Bilik-Bilik Pesantren Sebuah Potret Perjalanan”, Jakarta: Paramadina.

Margaret. M. Poloma, (1994), “Sosiologi Kontemporer”. Jakarta: PT Raja Grafindo Persada.

Nash, Kate., (2000), “Contemporary Political Sociology”. United Kingdom: Wiley-Blackwell.

Ngarawula, Bonaventura., (2020), "Shifting Indigrnoius House Values In Local Communities", International Journal of Psychological Rehabilitation, Vol 4, Issue 02, 2020, ISSN 1475-7192.

Noor, Mohammad dkk. (2004), "Visi Kebangsaan Religius: Refleksi Pemikiran dan Perjuangan TGKH Muhammad Zainuddin Abdul Madjid". Wacana Ilmu.

Ralf Dahrendorf, (1968), "Essays in the Theory of Society", Stanford, Calif.: Stanford University Press.

Rita L. Atkinson, Richard C. Atiknson, Ernest R. Hilgard., (1983), "Pengantar Psikologi Edisi Kedelapan”. Jakarta: Erlangga.

Soeprapto, Riyadi., (2001), “Interaksionisme Simbolik Perspektif Sosiologi Modern”. Malang: Averroes Press. Soerjono Soekanto. (1992), "Sosiologi Suatu Pengantar", Jakarta, Rajawali Press.

Sudjono Prasodjo. (1982), "Profil Pesantren", Jakarta: LP3S.

Urry, John. (2000). "Metaphors". Sociology Beyond Societies: Mobilities For The Twenty-First Century. Routledge.

Zamakhsyari, Dhofier. (1983). “Tradisi Pesantren Studi Tentang Pandangan Hidup Kyai”, LP3S, Jakarta. 